\title{
4
}

\section{Applications of Activated Carbons Obtained from Lignocellulosic Materials for the Wastewater Treatment}

\author{
Ma. del Rosario Moreno-Virgen, Rigoberto Tovar-Gómez, \\ Didilia I. Mendoza-Castillo and Adrián Bonilla-Petriciolet \\ Instituto Tecnológico de Aguascalientes \\ México
}

\section{Introduction}

Activated carbons are used in a number of industrial applications including separation and purification technologies, catalytic processes, biomedical engineering, and energy storage, among others. The extensive application of activated carbon is mainly due to its relatively lowcost with respect to other adsorbents, wide availability, high performance in adsorption processes, surface reactivity and the versatility to modify its physical and chemical properties for synthesizing adsorbents with very specific characteristics (Haro et al., 2011). In particular, the adsorption on activated carbon is the most used method for wastewater treatment because it is considered a low-cost purification process where trace amounts of several pollutants can be effectively removed from aqueous solution. Recently, the demand of activated carbons has increased significantly as a water-purifying agent to reduce the environmental risks caused by the water pollution worldwide (Altenor et al., 2009; Bello-Huitle et al., 2010).

Traditionally, the activated carbons used in wastewater treatment are obtained from coal/lignite, wood or animal bones but, recently, there is a growing interest in the use of alternative and low-cost precursors for their production (Altenor et al., 2009; ElizaldeGonzález \& Hernández-Montoya, 2007; Mohamed et al., 2010). Specifically, lignocellulosic wastes are a low-cost natural carbon source for the synthesis of several materials including the production of activated carbons. In this context, it is convenient to remark that natural resources play a dominant role in the economic activities and the utilization of lignocellulosic wastes for the synthesis of valuable commercial products may contribute to the economic development and to prevent environment pollution especially in developing countries (Satyanarayana et al., 2007). Therefore, lignocellulosic materials are considered as an interesting and important natural resource for production of activated carbons based on the fact that several billion tons of these materials are available (Mohamed et al., 2010; Satyanarayana et al., 2007). Actually, these precursors are considered as the most appropriate candidates for a cost-effective preparation of activated carbons (Silvestre-Albero et al., 2012). 
The production of activated carbons from lignocellulosic wastes is usually justified by two factors: the unique properties of these precursors and the possibility of mass production at an affordable cost. Several studies reported in literature indicate that it is possible to produce high quality activated carbons from raw lignocellulosic materials. These carbons are suitable for different applications including the removal of various pollutants from both drinking water and wastewaters. These pollutants include dyes, heavy metals, fluorides, phenols and other organic and inorganic toxic compounds, which are considered as priority substances for wastewater treatment in several countries (Altenor et al., 2009).

As indicated in Chapter 1, several raw lignocellulosic materials are available worldwide and they have been used in the synthesis of activated carbons for water purification. The performance of these activated carbons in the removal of a specific pollutant depends on both the surface chemistry and the textural properties (Altenor et al., 2009; ElizaldeGonzález \& Hernández-Montoya, 2007). Specifically, the properties of activated carbons such as the surface area, the pore size distribution, the presence of functional groups, and other physical and chemical parameters play an important role in the adsorption process of a given pollutant (Altenor et al., 2009). Previous chapters showed that these properties of activated carbon are mainly function of the precursor and of the type of thermal and activation process (Elizalde-González \& Hernández-Montoya, 2007; Mohamed et al., 2010). As expected, activated carbons obtained from different precursors and synthesis procedures will show different adsorption properties for the removal of a given pollutant.

Considering the importance of these materials in the context of environmental pollution control, this chapter provides an overview of the application of activated carbons obtained from lignocellulosic precursors for wastewater treatment. This chapter summarizes studies reported mainly from the year 2000. Our analysis and discussion are focused on the performance of different activated carbons obtained from several precursors and their capabilities for the removal of relevant and toxic pollutants from water. The remainder of this chapter is organized as follows. In Section 2, we briefly introduce the activated carbon types obtained from different precursors and synthesis procedures used in the context of wastewater treatment. This discussion also comprises the use of several activated carbons for the removal of priority water pollutants. Section 3 provides the description of removal mechanisms, while some key aspects of carbon regeneration are reported in Section 4. Finally, in Section 5 we provide some remarks and conclusions about the application of lignocellulosic precursors for producing activated carbons for wastewater treatment and desalination.

\section{Description of activated carbons for wastewater treatment and desalination}

\subsection{Synthesis, precursors and properties}

To date, different lignocellulosic precursors have been used for the synthesis of activated carbons for water treatment. As stated in Chapter 2, activated carbons can be obtained from a variety of raw lignocellulosic materials and by different processing methods. Table 1 shows a summary of the most common precursors and synthesis conditions, including physical and chemical activation agents, used for the preparation of activated carbons for the removal of priority water pollutants. In general, a wide variety of activated carbons 
obtained from lignocellulosic precursor have been mainly used for the removal of heavy metals, dyes and phenol compounds.

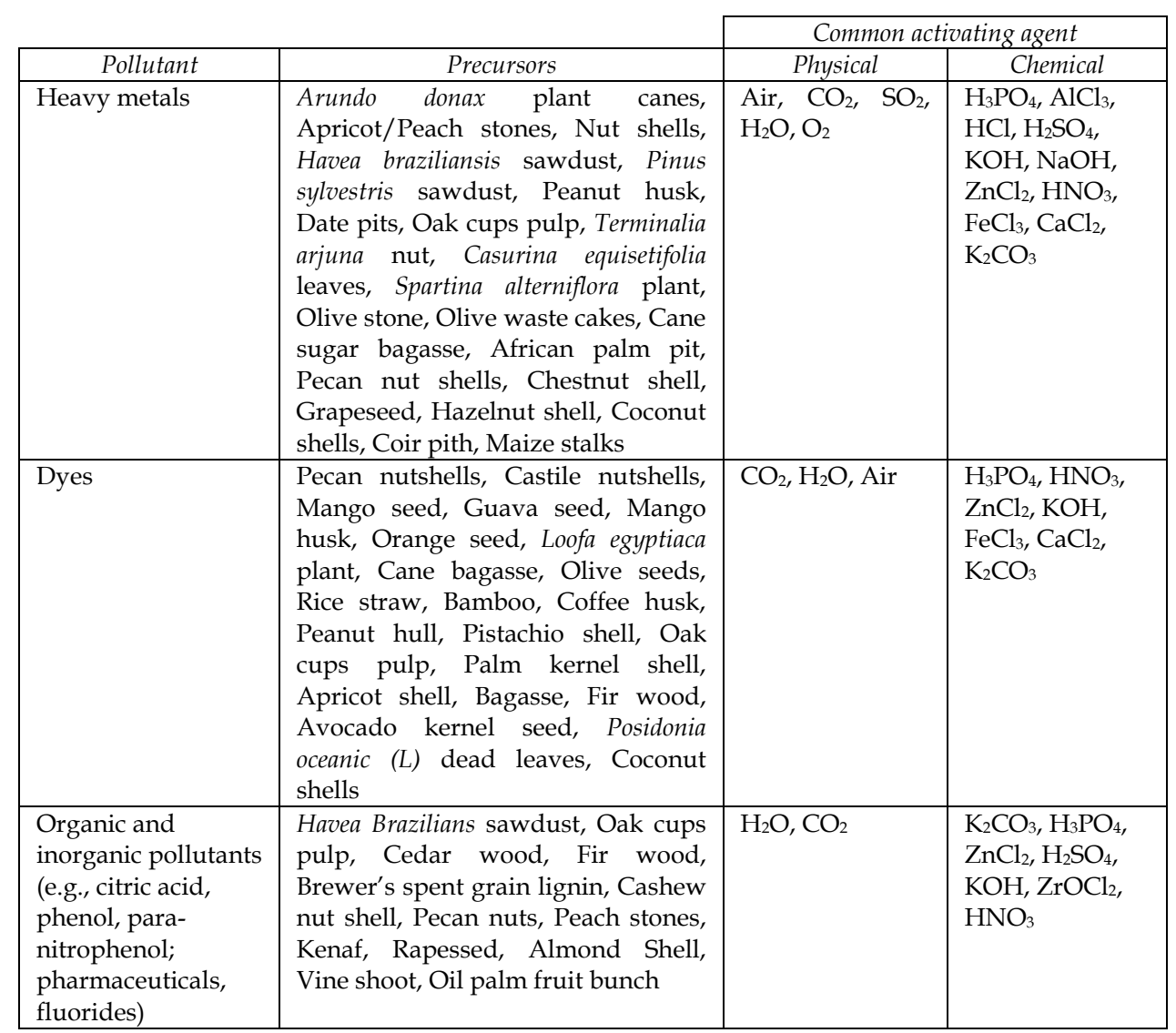

Table 1. Lignocellulosic precursors and activating agents used in the synthesis of activated carbons for wastewater treatment and desalination.

It appears that the most studied precursors are bamboo, cane bagasse, olive wastes, plants and fruit wastes. It is important to remark that different activating agents can be used for improving the adsorption properties of these carbons and they include, for example, $\mathrm{KOH}$, $\mathrm{ZnCl}_{2}, \mathrm{H}_{2} \mathrm{SO}_{4}, \mathrm{H}_{3} \mathrm{PO}_{4}, \mathrm{HNO}_{3}$ and $\mathrm{CO}_{2}$. However, the chemical activation with both $\mathrm{ZnCl}_{2}$ and $\mathrm{H}_{3} \mathrm{PO}_{4}$ appears to be the most used procedure for the preparation of adsorbents for water purification. As stated in Chapter $3, \mathrm{H}_{3} \mathrm{PO}_{4}$ is a widely used activating agent for the preparation of activated carbons for wastewater treatment probably due to it can be removed easily after carbon activation by washing with hot and cold water besides its other operational and environmental advantages. On the other hand, the carbonization temperature usually used for the synthesis of these adsorbent ranges from 400 to $1000{ }^{\circ} \mathrm{C}$. A summary of representative textural properties of some activated carbons are reported in Table 2. As expected, these activated carbons show a wide range of textural properties and 
surface chemistry which are determined by the conditions of the production process. For example, the studied activated carbons for wastewater treatment have surface areas from 100 to $1000 \mathrm{~m}^{2} / \mathrm{g}$.

\begin{tabular}{|c|c|c|c|c|}
\hline Precursor & $\begin{array}{l}\text { Specific surface } \\
\text { area, } m^{2} / g\end{array}$ & $\begin{array}{c}\text { Total pore } \\
\text { volume, } \mathrm{cm}^{3} / \mathrm{g}\end{array}$ & $\begin{array}{c}\text { Mean pore } \\
\text { diameter, } n m\end{array}$ & Reference \\
\hline $\begin{array}{l}\text { Arundo donax plant } \\
\text { canes }\end{array}$ & $1043-1194$ & $0.83-1.08$ & $1.5-1.9$ & Basso et al. (2002) \\
\hline Apricot stones & $1249-1685$ & $0.54-0.82$ & $1.0-3.0$ & Puziy et al. (2007) \\
\hline Bamboo & $758-2471$ & $0.42-1.34$ & $2.2-3.4$ & Chan et al. (2009) \\
\hline Cedar wood & $846-1492$ & $0.49-0.87$ & $1.8-2.2$ & Cuerda-Correa et al. (2006) \\
\hline Coir pith & $167-910$ & $0.12-0.36$ & $1.6-2.8$ & $\begin{array}{l}\text { Namasivayam \& Sangeetha } \\
(2006)\end{array}$ \\
\hline Fit wood & $891-2794$ & $0.61-1.54$ & $2.2-3.1$ & Wu et al. (2005) \\
\hline Guava seed & $52-598$ & $0.12-0.50$ & $3.3-8.9$ & $\begin{array}{l}\text { Elizalde-González \& } \\
\text { Hernández-Montoya (2009) }\end{array}$ \\
\hline Maize talks & $196-1523$ & $0.13-0.76$ & $1.6-2.7$ & El-Hendawy (2009) \\
\hline Mango husk & $254-535$ & $0.23-0.38$ & $2.8-4.1$ & $\begin{array}{l}\text { Elizalde-González \& } \\
\text { Hernández-Montoya (2008) }\end{array}$ \\
\hline Orange seed & $1-22$ & $0.04-0.05$ & $6.8-50.0$ & $\begin{array}{l}\text { Elizalde-González \& } \\
\text { Hernández-Montoya (2008) }\end{array}$ \\
\hline Pecan shell & $27-1071$ & $0.02-0.57$ & 2.0 & $\begin{array}{l}\text { Dastgheib \& Rockstraw } \\
\text { (2001) }\end{array}$ \\
\hline
\end{tabular}

Table 2. Textural parameters of selected activated carbons obtained from lignocellulosic precursors for water treatment.

\subsection{Applications in wastewater treatment and desalination}

As indicated, most of activated carbons obtained from lignocellulosic precursors can be used for the removal of both organic and inorganic compounds especially heavy metals, dyes and phenol compounds. Until now, various adsorption kinetic and equilibrium experiments have been performed in the literature to study the adsorption process of priority water pollutants using lignocellulosic-based activated carbons. In general, these studies have been performed at batch conditions and a limited number of studies using dynamic conditions (i.e., packed bed columns) have been reported. With illustrative purposes, the application of several activated carbons for the adsorption of relevant water pollutants is discussed below.

\subsubsection{Heavy metals}

Water pollution by heavy metals is considered a serious environmental problem due to their toxicity, long persistence, bioaccumulation and biomagnifications in food chain (Wojnarovits et al., 2010). In fact, heavy metals are toxic to aquatic flora, animals and human beings even at relatively low concentrations (Tajar et al., 2009). Chromium, cadmium and lead are considered the most common hazardous metals found in wastewaters of several industries. Particularly, the adsorption of these heavy metals on activated carbons is the most used treatment method to reach water pollution regulations and environmental standards. A great variety of lignocellusic precursors and activating agents has been used for the preparation of activated carbons for heavy metal removal (see Table 3). In general, these precursors include plant canes, chestnut shell, cane sugar bagasse, coconut shell, 
maize talks, pecan nut, olive wastes and coir pith, among others. Both chemical and physical activation procedures have been used for the preparation of activated carbons for removal of metal ions. Some illustrative applications are described below.

\begin{tabular}{|c|c|c|c|c|}
\hline Precursor & $\begin{array}{l}\text { Activating } \\
\text { agent }\end{array}$ & $\begin{array}{l}\text { Carbonization } \\
\text { temperature, }{ }^{\circ} \mathrm{C}\end{array}$ & Pollutant & Reference \\
\hline $\begin{array}{l}\text { Arundo donax } \\
\text { plant canes }\end{array}$ & $\begin{array}{l}\mathrm{H}_{3} \mathrm{PO}_{4} \text {, Air, } \\
\mathrm{CO}_{2}\end{array}$ & 500 & $\begin{array}{l}\text { Cadmium } \\
\text { Nickel }\end{array}$ & Basso et al. (2002) \\
\hline Nut shells & $\mathrm{H}_{3} \mathrm{PO}_{4}, \mathrm{SO}_{2}$ & 475 & Cadmium & Tajar et al. (2009) \\
\hline $\begin{array}{l}\text { Spartina } \\
\text { alterniflora } \\
\text { plant }\end{array}$ & $\mathrm{H}_{3} \mathrm{PO}_{4}$ & $400-700$ & Cadmium & Wang et al. (2011) \\
\hline $\begin{array}{l}\text { Apricot/Peach } \\
\text { stones }\end{array}$ & $\mathrm{H}_{3} \mathrm{PO}_{4}, \mathrm{Air}$ & $400-1000$ & Copper & Puziy et al. (2007) \\
\hline Chestnut shell & $\mathrm{ZnCl}_{2}$ & 550 & Copper & $\begin{array}{l}\text { Ozcimen \& Ersoy-Mericboyu } \\
(2008)\end{array}$ \\
\hline Grapeseed & $\mathrm{ZnCl}_{2}$ & 550 & Copper & $\begin{array}{l}\text { Ozcimen \& Ersoy-Mericboyu } \\
(2008)\end{array}$ \\
\hline Pecan shell & Air, $\mathrm{H}_{3} \mathrm{PO}_{4}$ & $300-500$ & Copper & Dastgheib \& Rockstraw (2001) \\
\hline Olive wastes & $\mathrm{H}_{3} \mathrm{PO}_{4}$ & $350-650$ & Copper & Baccar et al. (2009) \\
\hline $\begin{array}{l}\text { Pinus sylvestris } \\
\text { sawdust }\end{array}$ & $\begin{array}{l}\mathrm{HCl}, \mathrm{H}_{3} \mathrm{PO}_{4} \\
\mathrm{NaOH}, \mathrm{H}_{2} \mathrm{SO}_{4}\end{array}$ & $450-650$ & Chromium & Álvarez et al. (2007) \\
\hline Oak cups pulp & $\mathrm{H}_{3} \mathrm{PO}_{4}, \mathrm{ZnCl}_{2}$ & 600 & Chromium & Timur et al. (2010) \\
\hline Coconut palm & $\mathrm{H}_{2} \mathrm{O}, \mathrm{O}_{2}$ & 800 & \begin{tabular}{|l|} 
Copper \\
Cadmium \\
Chromium \\
\end{tabular} & de Lima et al. (2011) \\
\hline \begin{tabular}{ll|} 
Cane sugar \\
bagasse
\end{tabular} & $\mathrm{HNO}_{3}$, Steam & 900 & Lead & Giraldo \& Moreno-Piraján (2008) \\
\hline $\begin{array}{l}\text { African palm } \\
\text { pit }\end{array}$ & $\mathrm{HNO}_{3}$, Steam & 900 & Lead & Giraldo \& Moreno-Piraján (2008) \\
\hline $\begin{array}{l}\text { Pecan nut } \\
\text { shells }\end{array}$ & $\begin{array}{l}\mathrm{H}_{3} \mathrm{PO}_{4}, \\
\text { Calcium } \\
\text { solution }\end{array}$ & 800 & Lead & Hernández-Montoya et al. (2011) \\
\hline Maize talks & $\mathrm{KOH}$ & 700 & Lead & El-Hendawy (2009) \\
\hline Coconut shell & $\begin{array}{l}\mathrm{FeCl}_{3}, \mathrm{ZnCl}_{2} \\
\mathrm{CaCl}_{2}, \mathrm{~K}_{2} \mathrm{CO}_{3}\end{array}$ & $500-800$ & \begin{tabular}{|l} 
Lead \\
Copper \\
Mercury \\
\end{tabular} & Gimba et al. (2009) \\
\hline Coir pith & $\mathrm{ZnCl}_{2}$ & 700 & \begin{tabular}{|l|} 
Nickel \\
Mercury \\
Chromium \\
\end{tabular} & Namasivayam \& Sangeetha (2006) \\
\hline
\end{tabular}

Table 3. Synthesis conditions of activated carbons obtained from lignocellulosic precursors for heavy metal removal.

Chromium is considered a hazardous pollutant worldwide because of it is a mutagen and potential carcinogen. This pollutant is generated by several industries including metallurgy, leather tanning, and electroplating. In particular, water pollution caused by chromium is an important environmental problem in México and other developing countries. Until now, different lignocellulosic precursors have been used for the preparation of activated carbon for chromium removal. For example, Álvarez et al. (2007) reported the chromium adsorption using activated carbons obtained from Pinus sylvestris sawdust and different 
activation procedures. The activated carbons obtained from this precursor and different activating agents (i.e., $\mathrm{HCl}, \mathrm{H}_{3} \mathrm{PO}_{4}, \mathrm{H}_{2} \mathrm{SO}_{4}, \mathrm{AlCl}_{3}, \mathrm{NaOH}$ ) showed different textural properties. This study suggested that the chromium adsorption may be controlled by a chemical or physical mechanism depending upon the used carbon activating agent. In general, activated carbons obtained with acid treatments exhibited the highest chromium adsorption especially those obtained by $\mathrm{H}_{3} \mathrm{PO}_{4}$ treatment. In other study, Timur et al. (2010) prepared activated carbons from oak cups pulp using $\mathrm{H}_{3} \mathrm{PO}_{4}$ and $\mathrm{ZnCl}_{2}$ for chromium removal. These carbons have similar adsorption capacities, which are higher than $140 \mathrm{mg} / \mathrm{g}$. These adsorption capacities are higher than those obtained from other lignocellusosic precursors treated with $\mathrm{ZnCl}_{2}$ such as Terminalia arjuna nut $(28 \mathrm{mg} / \mathrm{g})$ and Casurina equisetifolia leaves $(35 \mathrm{mg} / \mathrm{g}$ ). Activated carbons prepared from coconut shell have been also used for chromium removal from water (de Lima et al., 2011). In particular, these adsorbents may show adsorption capacities up to $10 \mathrm{mg} / \mathrm{g}$.

On the other hand, cadmium is also an important heavy metal in the context of environmental pollution control because its presence in water, even at very low concentrations, is harmful to aquatic environment and human health (Wang et al., 2011). This metal is also considered as a priority water pollutant in several countries. Several raw lignocellulosic materials have been employed as precursors for the preparation of activated carbons for cadmium adsorption. For example, Basso et al. (2002) studied the preparation of activated carbons from Arundo donax plant canes and phosphoric acid activation for the removal of cadmium and nickel ions. Arundo donax L. belongs to grass species and is a plant that attains heights of $40 \mathrm{ft}$ and tends to form large, continuous root masses (Basso et al., 2002). This plant is considered as one of the most promising grass species for non-food uses because of it high biomass yield potential. Several activated carbons were prepared using this precursor at different atmospheres (i.e., air, $\mathrm{CO}_{2}$ and $\mathrm{N}_{2}$ ). This study concluded that activated carbons with the highest total content of surface oxygen functional groups showed the best adsorption capacity for heavy metal removal. A nut shell-based activated carbon obtained by chemical activation using $\mathrm{H}_{3} \mathrm{PO}_{4}$ and $\mathrm{SO}_{2}$ has been also studied (Tajar et al., 2009). The surface modification of activated carbon from nutshells using these activation agents improves the cadmium adsorption properties. In other study, activated carbons obtained from coconut shells and different activating salts $\left(\mathrm{FeCl}_{3}, \mathrm{ZnCl}_{2}, \mathrm{CaCl}_{2}\right.$ and $\left.\mathrm{K}_{2} \mathrm{CO}_{3}\right)$ were employed for adsorption of cadmium ions (Gimba et al., 2009). In particular, adsorbents treated with $\mathrm{CaCl}_{2}$ and $\mathrm{K}_{2} \mathrm{CO}_{3}$ showed the best removal performance. Alternatively, other precursors such as Spartina alterniflora plant (Wang et al., 2011) and coconut shell (de Lima et al., 2011) can be used for preparing adsorbents for cadmium removal.

Lead has been classified as a serious hazardous heavy metal because of it is extremely toxic for human beings. This metal is commonly detected in several industrial wastewaters from mining, smelting, metal plating and dying processes. Therefore, special attention has been given to develop proper adsorbents for lead removal from water. Specifically, Giraldo \& Moreno-Piraján (2008) reported the adsorption of lead ions using activated carbons with high surface area obtained from cane sugar bagasse and African palm pit. These precursors were activated using $\mathrm{HNO}_{3}$. In other study, activated carbons obtained from single step steam pyrolysis of sawdust of rubber wood were used for the simultaneous removal of lead 
and citric acid (Sreejalekshmit et al., 2009). Note that metal processing industries may discharge several pollutants including both heavy metals and organic chelating ligands such as citric acid and tartaric acid. Based on this fact, it is convenient to study the adsorption performance of activated carbons in multicomponent systems. These authors concluded that the presence of citric acid improves the adsorption capacity of this activated carbon. It appears that the functional $-\mathrm{COOH}$ groups of the adsorbed citric acid acted as new adsorption sites for lead on the activated carbon surface. Other adsorbents obtained from chemical activation of coconut shells (Gimba et al., 2009) and maize talks (El-Hendawy, 2009) can be used for lead adsorption. In particular, the synthesis of high performance activated carbons is feasible using maize talks and $\mathrm{KOH}$ activation. This adsorbent may show lead adsorption capacities up to $347 \mathrm{mg} / \mathrm{g}$. Note that recent studies have showed that it is possible to use natural wastes (e.g., egg shell residues) to produce alternative and lowcost activating agents for improving the adsorption properties of activated carbons for heavy metal removal (Hernández-Montoya et al., 2011). One example is the activated carbon obtained from pecan nutshells, $\mathrm{H}_{3} \mathrm{PO}_{4}$ and a calcium solution extracted from egg shells, which have been used for the removal of lead ions.

Finally, removal studies for other heavy metals include the adsorption of mercury using coconut shell activated carbons (Gimba et al., 2009), the removal of nickel and mercury using $\mathrm{ZnCl}_{2}$ activated coir pith carbon (Namasivayam \& Sangeetha, 2006), and the copper adsorption employing carbons from pecan shell (Dastgheib \& Rockstraw, 2001), fruit stones (Puziy et al., 2007), hazelnut shell (Dermibas et al., 2009), chestnut shell and grapeseed (Ozcimen \& Ersoy-Mericboyu, 2009), olive-waste (Baccar et al., 2009) and coconut palm (de Lima et al., 2011).

\begin{tabular}{|l|c|c|c|c|l|}
\cline { 3 - 6 } \multicolumn{1}{c|}{ Precursor } & Pollutant & $p H$ & $\begin{array}{c}\text { Conditions } \\
\text { o }\end{array}$ & $q_{\max }, m g / g$ & \multicolumn{1}{|c|}{ Reference } \\
\hline Arundo donax plant & Cadmium & 5.8 & 28 & 57.3 & Basso et al. (2002) \\
\hline Nut shells & Cadmium & 6 & 25 & $90-120$ & Tajar et al. (2009) \\
\hline Pecan shell & Copper & $2-5$ & 25 & $33-40$ & Dastgheib \& Rockstraw (2001) \\
\hline $\begin{array}{l}\text { Pinus sylvestris } \\
\text { sawdust }\end{array}$ & Chromium & $1-9$ & - & $0.5-1.83$ & Álvarez et al. (2007) \\
\hline African palm pit & Lead & $2-8$ & 25 & $4.7-15.2$ & $\begin{array}{l}\text { Giraldo \& Moreno-Piraján } \\
(2008)\end{array}$ \\
\hline Cane sugar bagasse & Lead & $2-8$ & 25 & $6.4-13.7$ & $\begin{array}{l}\text { Giraldo \& Moreno-Piraján } \\
(2008)\end{array}$ \\
\hline Maize talks & Lead & - & 25 & $88-347$ & El-Hendawy (2009) \\
\hline Pecan nut & Lead & 5 & 30 & 75.4 & $\begin{array}{l}\text { Hernández-Montoya et al. } \\
(2011)\end{array}$ \\
\hline Arundo donax plant & Nickel & 5.8 & 28 & 25.8 & Basso et al. (2002) \\
\hline
\end{tabular}

Table 4. Adsorption capacities of selected activated carbons obtained from lignocellulosic precursors for heavy metal removal from water.

In general, literature indicates that the chemical activation using $\mathrm{HNO}_{3}$ and $\mathrm{H}_{3} \mathrm{PO}_{4}$ improves the adsorption properties of activated carbons for heavy metal removal (Giraldo \& MorenoPiraján, 2008; Puziy et al., 2007). Specially, the presence of heteroatoms, in particular oxygen, may enhance the adsorption properties of these adsorbents. In summary, the adsorption 
capacities of lignocellulosic activated carbons for heavy metals may range from 10 to 100 $\mathrm{mg} / \mathrm{g}$ depending on the precursor type and activation procedure. Adsorption capacities for selected lignocellulosic activated carbons are reported in Table 4.

\subsubsection{Dyes}

Water pollution by dyes is an important environmental problem because these pollutants are toxic and may be carcinogenic. Dyes can affect the physical and chemical properties of water and the aquatic flora and fauna. It has been estimated that about $7 \times 10^{5}$ tons of dyes are generated annually worldwide by several industrial activities. In general, dyes exhibit a wide range of different chemical structures and properties and can be classified according to chemical constitution, application and end use. Typical dyes used in industrial processes include acid, basic, direct, disperse and reactive (Dermibas, 2009). In general, dyes are usually resistant to classical biodegradation and the adsorption process is an effective treatment method for their removal (Demirbas et al., 2009). Table 5 reports some examples of activated carbons used for dye removal from water.

\begin{tabular}{|c|c|c|c|c|}
\hline Precursor & $\begin{array}{c}\text { Activating } \\
\text { agent }\end{array}$ & $\begin{array}{l}\text { Carbonization } \\
\text { temperature, }{ }^{\circ} \mathrm{C}\end{array}$ & Pollutant & Reference \\
\hline Bamboo & $\mathrm{H}_{3} \mathrm{PO}_{4}$ & $400-600$ & $\begin{array}{l}\text { Acid blue } 25 \\
\text { Acid yellow } 117\end{array}$ & $\begin{array}{l}\text { Chan et al. (2008) } \\
\text { Chan et al. (2009) }\end{array}$ \\
\hline Castile nutshells & $\mathrm{H}_{3} \mathrm{PO}_{4}$ & 500 & Methylene blue & Bello-Huitle et al. (2010) \\
\hline Coconut shell & $\begin{array}{l}\mathrm{FeCl}_{3}, \\
\mathrm{ZnCl}_{2}, \\
\mathrm{CaCl}_{2} \\
\mathrm{~K}_{2} \mathrm{CO}_{3}\end{array}$ & $500-800$ & Indigo blue & Gimba et al. (2009) \\
\hline Fit wood & $\begin{array}{l}\mathrm{H}_{2} \mathrm{O} \\
\mathrm{KOH}\end{array}$ & 780,900 & $\begin{array}{l}\text { Acid blue } 74 \\
\text { Basic brown } 1 \\
\text { Methylene blue }\end{array}$ & Wu et al. (2005) \\
\hline Loofa egyptiaca plant & $\begin{array}{l}\mathrm{H}_{3} \mathrm{PO}_{4}, \\
\mathrm{HNO}_{3}, \\
\mathrm{ZnCl}_{2}\end{array}$ & 500 & Direct blue 106 & El-Ashtoukhy (2009) \\
\hline Oak cups pulp & $\begin{array}{l}\mathrm{H}_{3} \mathrm{PO}_{4}, \\
\mathrm{ZnCl}_{2}\end{array}$ & 600 & $\begin{array}{l}\text { Basic Red } 18 \\
\text { Acid Red } 111 \\
\text { Methylene Blue }\end{array}$ & Timur et al. (2010) \\
\hline Pecan nutshells & $\mathrm{H}_{3} \mathrm{PO}_{4}$ & 500 & Methylene blue & Bello-Huitle et al. (2010) \\
\hline Pecan nut shells & $\begin{array}{l}\mathrm{H}_{3} \mathrm{PO}_{4} \\
\text { Calcium } \\
\text { solution }\end{array}$ & 800 & Acid blue 25 & $\begin{array}{l}\text { Hernández-Montoya et al. } \\
\text { (2011) }\end{array}$ \\
\hline $\begin{array}{l}\text { P. oceanica }(L) \text { dead } \\
\text { leaves }\end{array}$ & $\mathrm{ZnCl}_{2}$ & 600 & Methylene blue & Dural et al. (2011) \\
\hline
\end{tabular}

Table 5. Synthesis conditions of activated carbons obtained from lignocellulosic precursors for dye removal.

Recently, Altenor et al. (2009) have reported a review of activated carbons obtained from lignocellulosic wastes for water treatment giving an emphasis to those adsorbents used for dye removal. Literature review indicates that several adsorption studies using activated carbons for acid dyes have been reported. It is convenient to observe that antraquinone acid dyes (e.g., acid blue 25) are the second most important dyes commercially used in the textile 
industry and they are considered priority pollutants due to its high toxicity and carcinogenic potential (Hernández-Montoya et al., 2011). However, few adsorption studies have been performed using these acid dyes.

Woods are the most common used precursors for preparing activated carbons for dye removal. During long time, wood activated carbons obtained from different chemical and physical treatments have been used for the removal of several dyes including Acid Blue 74, Basic Brown 1, and Methylene Blue (Wu et al., 2005). Additionally, bamboo wastes have been widely employed as a raw material for the synthesis of activated carbons for dye removal (Ahmad \& Hameed, 2010; Chan et al., 2008; Chan et al., 2009). Results of adsorption studies suggested that both surface area and porosity of these activated carbons play an important role in the removal process. Other precursors reported for dye removal include sugar industry wastes (Blanco-Castro et al., 2000), coir pith (Namasivayam \& Sangeetha, 2006), and coconut shells (Gimba et al., 2009), among other raw lignocellulosic materials.

It is convenient to remark that several fruits and crops have been considered as effective precursors for preparation of adsorbents for dye removal. Specifically, Elizalde-González et al. (2007) reported the adsorption of several basic, acid and reactive dyes from aqueous solutions by avocado activated carbons impregnated with $\mathrm{H}_{3} \mathrm{PO}_{4}$. In other study, ElizaldeGonzalez \& Hernandez-Montoya (2008) reported the removal of anthraquinone dyes (i.e., acid blue 80 and acid green 27) using activated carbons obtained from seeds of mango, guava and orange. These fruits are abundant and are considered as a low cost agricultural waste in México and other countries (Elizalde-González \& Hernández-Montoya, 2009). These studies indicated that the acid activated carbon obtained from orange seed was the most effective for the removal of acid green 27 from water despite its negligible specific surface; while the activated carbons obtained from mango seed were more effective for the removal of acid blue 80 . Authors concluded that the interaction between the functional groups of activated carbons and these dyes are very important in the adsorption process. In other study, guava seed was used as precursor of activated carbon for the removal of Acid orange 7 (AO7), which is a dye commonly used in tanneries, paper manufacturing and textile industry (Elizalde-Gónzalez \& Hernández-Montoya, 2009). The optimal conditions for the preparation of guava seed carbon for dye removal were identified using a Taguchi experimental design. Recently, Bello-Huitle et al. (2010) reported the removal of methylene blue dye from water using activated carbons obtained from pecan and castile nutshells. Both pecan and castile nutshells are important crops from México and other countries. In this study, $\mathrm{H}_{3} \mathrm{PO}_{4}$ was used as activating agent for these precursors. Adsorption studies indicated that the adsorption capacity of activated carbon obtained from pecan nutshells was higher than that obtained for castile nutshells. Finally, Hernández-Montoya et al. (2011) have reported the preparation of activated carbons for adsorption of acid blue 25 using both pecan nut shells and a calcium solution extracted from egg shell wastes. This adsorbent showed adsorption capacities up to $48 \mathrm{mg} / \mathrm{g}$.

With respect to precursors obtained from plant wastes, El-Ashtoukhy (2009) used the Loofa egyptiaca plant to prepare a low-cost activated carbon for the removal of direct blue 106. This plant is cultivated only in Egypt and is a highly branched, fibrous and interconnected cellulosic material. In this study, the adsorbents were obtained from the carbonization of 
this plant at $500{ }^{\circ} \mathrm{C}$ using $\mathrm{H}_{3} \mathrm{PO}_{4}, \mathrm{HNO}_{3}$ and $\mathrm{ZnCl}_{2}$ as activating agents. Adsorption kinetics and equilibrium studies were performed at $25^{\circ} \mathrm{C}$ and different conditions of $\mathrm{pH}$. Results showed that the maximum adsorption was obtained at $\mathrm{pH} 2$. On the other hand, the sea plant $P$. Occeanica $(L)$ can be also used as carbon precursor for methylene blue adsorption (Dural et al., 2011). In particular, kinetic and equilibrium adsorption studies of this dye were performed using an activated carbon obtained from this plant activated with $\mathrm{ZnCl}_{2}$. Carbon samples showed adsorption capacities up to $280 \mathrm{mg} / \mathrm{g}$ at tested conditions.

Usually, the dye adsorption appears to be higher using activated carbons obtained from $\mathrm{ZnCl}_{2}$ and $\mathrm{H}_{3} \mathrm{PO}_{4}$ activation. Adsorption capacities of lignocellulosic-based activated carbons may range from 50 to $400 \mathrm{mg} / \mathrm{g}$. For illustration, dye adsorption capacities for selected activated carbons are reported in Table 6.

\begin{tabular}{|l|c|c|c|c|l|}
\cline { 3 - 5 } \multicolumn{2}{c|}{} & \multicolumn{2}{c|}{ Conditions } & \multicolumn{1}{c|}{ Reference } \\
\hline \multicolumn{1}{|c|}{ Precursor } & Pollutant & $p H$ & $T,{ }^{\circ} \mathrm{C}$ & $q_{m a x}, \mathrm{mg} / \mathrm{g}$ & \multicolumn{1}{c|}{} \\
\hline $\begin{array}{l}\text { Loofa egyptiaca } \\
\text { plant }\end{array}$ & Direct blue 106 & $2-9$ & 25 & $63.3-73.5$ & El-Ashtoukhy (2009) \\
\hline $\begin{array}{l}\text { Castile } \\
\text { nutshells }\end{array}$ & Methylene blue & 7 & 20 & 169.5 & Bello-Huitle et al. (2010) \\
\hline Pecan nutshells & Methylene blue & 7 & 20 & 400 & Bello-Huitle et al. (2010) \\
\hline Pecan nut & Acid blue 25 & 6 & 30 & 48 & $\begin{array}{l}\text { Hernández-Montoya et al. } \\
\text { (2011) }\end{array}$ \\
\hline
\end{tabular}

Table 6. Adsorption capacities of selected activated carbons obtained from lignocellulosic precursors for dye removal from water.

\subsubsection{Phenol compounds}

Phenol and its derivatives are common pollutants present in a variety of effluents from plastic, gasoline, disinfectant, pesticides, pharmaceutical, and steel industries (Lin et al., 2009; Timur et al., 2010). In particular, phenol is an important toxic compound listed as a priority pollutant by the EPA and other environmental protection agencies because of its high toxicity and possible accumulation in the environment. This compound is considered toxic to human beings and, as a consequence, it must be removed before the discharge of wastewaters. Until now, different adsorbents have been reported for the removal of phenol and its derivative compounds, see Table 7.

Specifically, batch experiments for phenol adsorption were performed using microporous activated carbons obtained from both kenaf and rapeseed precursors (Nabais et al., 2009). In particular, the phenol adsorption capacities of both adsorbents were higher than $70 \mathrm{mg} / \mathrm{g}$. In other study, Alam et al. (2009) studied the effect of different synthesis conditions of activated carbon obtained from oil palm empty fruit bunches on phenol removal. These parameters include temperature, activation time and $\mathrm{CO}_{2}$ flow rate. In general, these carbons showed phenol adsorption capacities from 1.03 to $4.83 \mathrm{mg} / \mathrm{g}$. Recently, Bello-Huitle et al. (2010) studied the removal of phenol using activated carbons obtained by chemical activation and pyrolysis of pecan and castile nutshells. These authors synthesized different samples of activated carbons using these crops and adsorption isotherms were performed at $20^{\circ} \mathrm{C}$ and $\mathrm{pH}$ 7. This study indicated that the activated carbon from pecan nutshells showed better phenol uptakes. On the other hand, Timur et al. (2010) reported that activated carbons 
obtained from oak cups pulp using $\mathrm{ZnCl}_{2}$ have higher phenol adsorption capacities than those obtained for activated carbons produced with $\mathrm{H}_{3} \mathrm{PO}_{4}$. They suggested that this best performance was related to the lower amount of acidic surface groups on activated carbon.

\begin{tabular}{|l|l|l|l|l|}
\hline Precursor & $\begin{array}{l}\text { Activating } \\
\text { agent }\end{array}$ & $\begin{array}{l}\text { Carbonization } \\
\text { temperature, }{ }^{\circ} \mathrm{C}\end{array}$ & Pollutant & Reference \\
\hline $\begin{array}{l}\text { Castile } \\
\text { nutshells }\end{array}$ & $\mathrm{H}_{3} \mathrm{PO}_{4}$ & 500 & Phenol & Bello-Huitle et al. (2010) \\
\hline Coir pith & $\mathrm{ZnCl}_{2}$ & 700 & Phenol & $\begin{array}{l}\text { Namasivayam \& Sangeetha } \\
(2006)\end{array}$ \\
\hline Kenaf & $\mathrm{CO}_{2}, \mathrm{HNO}_{3}$ & 700 & Phenol & Nabais et al. (2009) \\
\hline $\begin{array}{l}\text { Oak cups } \\
\text { pulp }\end{array}$ & $\begin{array}{l}\mathrm{H}_{3} \mathrm{PO}_{4}, \\
\mathrm{ZnCl}_{2}\end{array}$ & 600 & Phenol & Timur et al. (2010) \\
\hline $\begin{array}{l}\text { Pecan } \\
\text { nutshells }\end{array}$ & $\mathrm{H}_{3} \mathrm{PO}_{4}$ & 500 & Phenol & Bello-Huitle et al. (2010) \\
\hline Rapessed & $\mathrm{CO}_{2}, \mathrm{HNO}_{3}$ & 700 & $\begin{array}{l}\text { Phenol } \\
\text { p-nitrophenol }\end{array}$ & Mabais et al. (2009) \\
\hline $\begin{array}{l}\text { Vine shoot } \\
\mathrm{CO}_{2}, \mathrm{HNO}_{3}\end{array}$ & 800 & $\begin{array}{l}\text { Phenol } \\
\text { p-nitrophenol }\end{array}$ & Mourao et al. (2011) \\
\hline $\begin{array}{l}\text { Almond } \\
\text { shell }\end{array}$ & $\mathrm{CO}_{2}, \mathrm{HNO}_{3}$ & 800 & p-nitrophenol & Cuerda-Correa et al. (2006) \\
\hline $\begin{array}{l}\text { Cedar } \\
\text { wood }\end{array}$ & $\mathrm{H}_{2} \mathrm{SO}_{4}, \mathrm{CO}_{2}$ & $600-800$ & $\begin{array}{l}\text { 2,4 dichlorophenol } \\
\text { 4-chlorophenol } \\
\text { p-cresol, phenol }\end{array}$ & Wu et al. (2005) \\
\hline Fit wood & $\mathrm{H}_{2} \mathrm{O}_{2} \mathrm{KOH}^{2}$ & 780,900 & ald & \\
\hline
\end{tabular}

Table 7. Synthesis conditions of activated carbons obtained from lignocellulosic precursors for removal of phenol compounds.

\begin{tabular}{|l|l|c|c|c|l|}
\cline { 3 - 4 } \multicolumn{2}{c|}{} & \multicolumn{2}{c|}{ Conditions } & \multicolumn{1}{c|}{ Reference } \\
\hline \multicolumn{1}{|c|}{ Precursor } & Pollutant & $p H$ & $T,{ }^{\circ} \mathrm{C}$ & $q_{\max }, \mathrm{mg} / \mathrm{g}$ & Mourao et al. (2011) \\
\hline Almond shell & Phenol & 3 & 25 & $76-139$ & Me10 \\
\hline Castile nutshells & Phenol & 7 & 20 & 53.2 & Bello-Huitle et al. (2010) \\
\hline Kenaf & Phenol & 7.5 & 25 & $45-80$ & Nabais et al. (2009) \\
\hline Pecan nutshells & Phenol & 7 & 20 & 158.7 & Bello-Huitle et al. (2010) \\
\hline Rapeseed & Phenol & 7.5 & 25 & $45-80$ & Nabais et al. (2009) \\
\hline Vine shoot & Phenol & 3 & 25 & 73 & Mourao et al. (2011) \\
\hline Almond shell & p-nitrophenol & 3 & 25 & $154-224$ & Mourao et al. (2011) \\
\hline Vine shoot & p-nitrophenol & 3 & 25 & $126-238$ & Mourao et al. (2011) \\
\hline
\end{tabular}

Table 8. Adsorption capacities of selected activated carbons obtained from lignocellulosic precursors for removal of phenol compounds from water.

Finally, it is important to note that the adsorption of other phenol-based organic compounds on different types of activated carbons has been also studied and they include, for example, the removal of p-nitrophenol using activated carbons obtained from cedar wood activated by $\mathrm{H}_{2} \mathrm{SO}_{4}$ (Cuerda-Correa et al., 2006), carbons from almond shell and vine shoot precursors activated with carbon dioxide and oxidized with nitric acid (Mourao et al., 2011), the adsorption of phenol-compounds using coir pith activated carbons (Namasivayam \& Sangeetha, 2006), or the removal of 2,4-dichloropenol, 4-chloropenol and p-cresol using $\mathrm{KOH}$ and steam-activated carbons obtained from Fir wood (Wu et al., 2005). Overall, these 
activated carbons showed adsorption capacities from 40 to $200 \mathrm{mg} / \mathrm{g}$. Table 8 shows the adsorption capacities of different activated carbons used for removal of phenol compounds.

\subsubsection{Other organic and inorganic toxic pollutants}

Activated carbons can be used for the removal of other organic and inorganic compounds such as nitrates, thyocyanate, selenite, vanadium, sulfates, molybdate, fluorides, and pharmaceuticals, among other pollutants (Namasivayam \& Sangeetha, 2006).

Drinking water sources in a number of developing and underdeveloped countries is polluted by toxic anions such as fluorides. Specifically, the presence of high fluoride concentrations in drinking water is a common problem in several countries including México, China and India (Alagumuthu \& Rajan, 2010; Hernández-Montoya et al., 2011). Fluoride concentrations in drinking water higher than $1.5 \mathrm{mg} / \mathrm{L}$ is the principal cause of dental fluorosis in children and may cause bone fluorosis if a chronic exposure occurs. Traditional lignocellulosic precursors and activation procedures are not suitable for the production of activated carbons suitable for fluoride removal from water. However, some studies have shown that fluoride ion has a strong affinity towards multivalent metal ions, e.g., $\mathrm{Al}^{3+}, \mathrm{Fe}^{3+}$ and $\mathrm{Zr}^{4+}$ (Alagumuthu \& Rajan, 2010) and also may interact with some bivalent ions such as calcium (Hernández-Montoya et al., 2011). Based on this fact, some studies have reported the application of non-conventional impregnating agents for the preparation of activated carbons for fluoride removal from water. For example, Alagumuthu \& Rajan (2010) studied the carbonization of cashew nut shell impregnated with zirconium oxy chloride. Cashew nut is one of the commercialized products of the cashew tree and the cashew nut shell is the waste product of cashew nut, which contains potassium and magnesium compounds. In general, adsorption capacities of this carbon were around $2.0 \mathrm{mg} / \mathrm{g}$ at tested conditions. These authors indicated that the fluoride adsorption was related to both electrostatic interactions and a chemisorption mechanism that involves chloride and hydroxide species of this carbon. In particular, the presence of zirconium species improves the adsorption properties of this adsorbent. A recent study showed that activated carbons obtained from pecan nut shells and egg shell wastes can be used for fluoride removal from water (Hernández-Montoya et al., 2012). This study concluded that the calcium chemical species on the carbon surface played an important role in the fluoride adsorption process.

On the other hand, activated carbons have been used for the removal of pharmaceuticals from water (e.g., Cabrita et al., 2010). Several pharmaceuticals are released to the environment via human and animal excreta and, as a consequence, trace quantities of these pollutants tend to accumulate in water resources. Cabrita et al. (2010) reported the removal of acetaminophen (i.e., paracetamol) from aqueous solution using an activated carbon from peach stones. This activated carbon is characterized by a high amount of oxygen functionalities, which appear to be related to the presence of pyrone and/or chromene-like type structures. This carbon showed an adsorption capacity higher than those obtained for activated carbon synthesized from plastic waste and commercial carbons. This study concluded that the adsorption of this pharmaceutical is a complex process that depends on both the chemical composition and the textural parameters of activated carbon. 
Recently, the performance of activated carbon has been studied and tested in the removal of new environmental pollutants originated from consumer products and by-products used in industrial, agricultural and other human activities. In particular, these emergent pollutants include pesticides, household-cleaning chemicals, fragrances, and disinfectants, among other organic and inorganic toxic compounds (Cabrita et al., 2010). Based on this perspective, it is expected that the applications of activated carbons obtained from lignocellulosic precursors will increase for wastewater treatment in forthcoming years.

\section{Description of adsorption mechanisms of priority water pollutants using activated carbons}

The surface chemistry of activated carbons plays an important role to determine their adsorption performance in wastewater treatment. In particular, the precursor has a critical effect on the surface chemistry properties of activated carbons (Wang et al., 2011). The presence of several functional groups on carbon surface (e.g., carboxylic, carbonyl, hydroxyl, ether, quinine, lactone, anhydride) implies the presence of many types of pollutant-carbon interactions (Wu et al., 2005). It is important to remark that the nature and prevalence of functional groups on carbon surface may be modified by activation methods.

Several studies have shown that the surface functional groups of activated carbons play an important role for the adsorption of a specific pollutant (Ould-Idriss et al., 2011). For example, polar or acidic oxygen functional groups on the surface of activated carbons have been recognized to play a fundamental role on metal adsorption (Basso et al., 2002). In fact, reported studies have shown the predominant influence of surface oxygen functional groups of activated carbons on metal uptake (Basso et al., 2002). For this application, the following trend has been identified: the higher the content of functional groups, the greater the adsorption extent of the activated carbon. These functional groups include: carbonyls, phenols, lactones and carboxylic acids (Basso et al., 2002). Also, activated carbons with sulfur functional groups are suitable for the removal of some heavy metals such as cadmium (Tajar et al., 2009). In the case of phenol and its derivatives compounds, the adsorption process is also related to the oxygen-containing surface functional groups (Tamir et al., 2010). Literature indicates that the most relevant heteroatoms for phenol adsorption are nitrogen and oxygen (Nabais et al., 2009).

On the other hand, cation-exchange mechanisms are also involved in the adsorption of some pollutants from water. Some studies have suggested that the cation-exchange properties of activated carbons are determined by the presence of oxygen- and phosphorous-containing surface groups. For example, Dastgheib \& Rockstraw (2001) reported that an ion-exchange and surface complexation with oxygen- and phosphorus-containing groups on pecan shell activated carbon may be involved in the adsorption of copper from water. This cation exchange capacity of activated carbons can be improved via chemical activation (Puziy et al., 2007). Usually, activated carbons obtained from carbonization and phosphoric acid activation may show a considerable cation exchange capacity.

Electrostatic interactions appear to play a key role in the adsorption mechanism of some pollutants including metals ions and dyes (Wang et al., 2011). For the case of some dyes, the 
adsorption process has been related to electrostatic force of attraction between dyes and activated carbon and also to complex formation (Tamir et al., 2010). In general, literature indicates that dye removal using activated carbons may imply several mechanisms including ion-dipole forces, ion exchange, hydrogen bonding and non-specific interactions. Also, phenol adsorption onto activated carbon may occur via a complex interplay of electrostatic and dispersion interactions (Nabais et al., 2009).

It is convenient to recall that the adsorption process using activated carbon depends on the operating conditions of removal process (i.e., adsorbent mass, pollutant concentration, operating mode), the adsorbent characteristics (e.g., functional groups, textural properties, etc.) and the solution chemistry (e.g., temperature, $\mathrm{pH}$, ionic strength). Based on this fact, diverse adsorption mechanisms may occur simultaneously during the removal of a specific pollutant using activated carbons synthesized from lignocellulosic precursors. Therefore, the identification and characterization of adsorption mechanisms involved in the removal of priority water pollutants is a relevant and important research topic for understanding the chemistry of activated carbons.

\section{Desorption and regeneration studies of activated carbons used in water treatment}

Adsorbent regeneration is an important operating parameter to establish the feasibility and the operating costs of water treatment processes using activated carbons. The performance and efficacy of desorbing agents depends on the carbon type, the concentration of sorbed pollutant, and the operating conditions of desorption process (e.g., concentration of desorbing agent, temperature and sorbent dosage).

In general, literature indicates that some regeneration studies have been performed using activated carbons obtained from lignocellulosic precursors loaded with some waster pollutants especially heavy metal ions. Specifically, copper desorption from pecan shell activated carbon has been studied using both water and $10 \% \mathrm{HCl}$ solution (Dastgheib \& Rockstraw, 2001). This study showed that copper desorption with water is not feasible, while $\mathrm{HCl}$ may recovery up to $98 \%$ of the copper adsorbed on pecan shell activated carbon. Basso et al. (2002) performed desorption studies to recovery cadmium and nickel ions adsorbed on activated carbons obtained from Arundo donax plant canes using $\mathrm{HCl}$. This study concluded that it is feasible to recovery the $90 \%$ of the metal ions loaded in these activated carbons. In other study, Tajar et al. (2009) reported preliminary results for desorption of cadmium from an activated carbon obtained from nutshells using $\mathrm{HCl}, \mathrm{HNO}_{3}$ and $\mathrm{H}_{2} \mathrm{SO}_{4}$ as extractants. It appears that $\mathrm{HCl}$ is an effective chemical for desorbing cadmium ions from this activated carbon. Authors concluded that $\mathrm{H}^{+}$ions from $\mathrm{HCl}$ displace cadmium ions bounded to the activated carbon during the desorption stage. Recently, the chromium desorption from activated carbon obtained from Pinus sylvestris sawdust has been studied using $\mathrm{H}_{2} \mathrm{SO}_{4}$ (Álvarez et al., 2007). Results of carbon regeneration showed that this activated carbon retains its chromium adsorption capacity during the first regeneration cycle. However, the adsorption performance of this adsorbent is substantially reduced in subsequent regeneration cycles. With respect to other pollutants, $\mathrm{HCl}$ and $\mathrm{NaOH}$ have been used for the fluoride desorption using a zirconium impregnated cashew nut shell 
carbon (Alagumuthu \& Rajan, 2010). These authors reported that $\mathrm{NaOH}$ was more effective for carbon regeneration and may recovery more than $95 \%$ of fluoride loaded on activated carbon.

In summary, a limited number of studies have been reported for the regeneration of activated carbons used for wastewater treatment. Therefore, further research should be performed to develop low-cost and effective regeneration procedures for activated carbons used in water purification.

\section{Conclusions}

This chapter describes the application of lignocellulosic precursors for the synthesis of activated carbons used in the removal of different pollutants from drinking water and wastewaters. In particular, lignocellulosic precursors can be used for the synthesis of activated carbons with attractive properties for the adsorption of different organic and inorganic pollutants. Literature indicates that we can prepare activated carbons with improved adsorption properties to remove effectively priority water pollutants by using the appropriate lignocellulosic precursors and by optimizing the conditions of carbonization and activation. In particular, research on activated carbon for wastewater treatment should give special attention in the optimization of synthesis conditions for improving adsorption properties to remove hazardous pollutants such as fluoride and arsenic. Also, the development of low-cost regeneration procedures is highlighted to reduce the costs of water treatment technologies. Finally, it is expected that the applications of activated carbons obtained from these precursors will increase for wastewater treatment and other science fields in forthcoming years.

\section{Acknowledgments}

Authors acknowledge the financial support provided by CONACYT, DGEST and Instituto Tecnológico de Aguascalientes (México).

\section{References}

[1] Ahmad, A.A. \& Hameed, B.H. (2010). Fixed-bed adsorption of reactive azo dye onto granular activated carbon prepared from waste. Journal of Hazardous Materials, Vol. 175, No. 1-3 (March 2010), pp. (298-303), ISSN 0304-3894.

[2] Alagumuthu, G. \& Rajan M. (2010). Equilibrium and kinetics of adsorption of fluoride onto zirconium impregnated cashew nut shell carbon. Chemical Engineering Journal, Vol. 158, No. 3 (April 2010), pp. (451-457), ISSN 1385-8947.

[3] Alam, M.Z., Ameem, E.S., Muyibi, S.A. \& Kabbashi, N.A. (2009). The factors affecting the performance of activated carbon prepared from oil palm empty fruit bunches for adsorption of phenol. Chemical Engineering Journal, Vol. 155, No. 1-2, (February 2011), pp. (191-198), ISSN 1385-8947.

[4] Álvarez, P., Blanco, C. \& Granda, M. (2007). The adsorption of chromium (VI) from industrial wastewater by acid and base-activated lignocellulosic residues. Journal of Hazardous Materials, Vol. 144, No. 1-2, (June 2007), pp. (400-405), ISSN 0304-3894. 
[5] Altenor, S., Carene-Melane, B. \& Gaspard, S. (2009). Activated carbons from lignocellulosic waste materials for water treatment: a review. International Journal of Environmental Technology and Management, Vol. 10, No. 3-4, pp. (308-326), ISSN 1466-2132.

[6] Baccar, R., Bouzid, J., Feki, M. \& Montiel A. (2009). Preparation of activated carbon from Tunisian olive-waste cakes and its application for adsorption of heavy metal ions. Journal of Hazardous Materials, Vol. 162, No. 2-3, (March 2009), pp. (1522-1529), ISSN 0304-3894.

[7] Basso, M.C., Cerrella, E.G. \& Cukierman A.K. (2002). Activated carbons developed from rapidly renewable bioresource for removal of cadmium (II) and nickel (II) ions from dilute aqueous solution. Industrial Engineering Chemical Research, Vol. 41, No. 2, (December 2001), pp. (180-189), ISSN 0888-5885.

[8] Bello-Huitle, V., Atenco-Fernández, P. \& Reyes-Mazzoco, R. (2010). Adsorption studies of methylene blue and phenol onto pecan and castile nutshells prepared by chemical activation. Revista Mexicana de Ingeniería Química, Vol. 9, No. 3, pp. (313-322), ISSN 1665-2738.

[9] Blanco-Castro, J., Bonelli, P., Cerrella E. \& Cukierman A.L. (2000). Phosphoric acid activation of agricultural residues and bagasse from sugar cane: influence of the experimental conditions on adsorption characteristics of activated carbons. Industrial Engineering Chemical Research, Vol. 39, No. 11, (September 2000), pp. (4166-4172), ISSN 0888-5885.

[10] Cabrita, I., Ruiz, B., Mestre, A.S., Fonseca, I.M., Carvalho, A.P. \& Ania C.O. (2010). Removal of an analgesic using activated carbons prepared from urban and industrial residues. Chemical Engineering Journal, Vol. 163, No. 3, (October 2010), pp. (249-255), ISSN 1385-8947.

[11] Chan, L.S., Cheung, W.H. \& McKay, G. (2008). Adsorption of acid dyes by bamboo derived activated carbon. Desalination, Vol. 218, No. 1-3, (January 2008), pp. (304-312), ISSN 0011-9164.

[12] Chan, L.S., Cheung, W.H. Allen, S.J. \& McKay G. (2009). Separation of acid-dyes mixture by bamboo derived active carbon. Separation and Purification Technology, Vol. 67, No. 2, (June 2009), pp. 166-172, ISSN 1383-5866.

[13] Cuerda-Correa, E.M., Díaz-Díez, M.A., Macías-García, A. \& Gañán-Gómez, J. (2006). Preparation of activated carbons previously treated with sulfuric acid. A study of their adsorption capacity in solution. Applied Surface Science, Vol. 252, No. 17, (June 2006), pp. (6042-6045), ISSN 0169-4332.

[14] Dastgheib, S.A. \& Rockstraw, D.A. (2001). Pecan shell activated carbons: synthesis, characterization, and application for the removal of copper from aqueous solution. Carbon, Vol. 39, No. 12, (October 2001), pp. (1849-1855), ISSN 0008-6223.

[15] de Lima, L.S., Machado-Araujo, M.D., Quináia, S.P., Migliorine, D.W. \& Garcia, J.R. (2011). Adsorption modeling of $\mathrm{Cr}, \mathrm{Cd}$ and $\mathrm{Cu}$ on activated carbon of different origins by using fractional factorial design. Chemical Engineering Journal, Vol. 166, No. 3, (February 2011), pp. (881-889), ISSN 1385-8947.

[16] Demirbas, A. (2009). Agricultural based activated carbons for the removal of dyes from aqueous solutions: A review. Journal of Hazardous Materials, Vol. 167, No. 1-3, (August 2009), pp. (1-9), ISSN 0304-3894.

[17] Dermibas, E., Dizge, N., Sulak, M.T. \& Kobya, M. (2009). Adsorption kinetics and equilibrium studies of copper from aqueous solutions using hazelnut shell activated carbon. Chemical Engineering Journal, Vol. 148, No. 2-3, (May 2009), pp. (480-487), ISSN 1385-8947. 
[18] Dural, M.U., Cavas, L., Papageorgious, S.K. \& Katsaros, F.K. (2011). Methylene blue adsorption on activated carbon prepared from Posidonia oceánica (L) dead leaves: kinetics and equilibrium studies. Chemical Engineering Journal, Vol. 168, No. 1, (March 2011), pp. (77-85), ISSN 1385-8947.

[19] El Ashtoukhy E.S.Z. (2009). Loofa egyptiaca as a novel adsorbent for removal of direct blue dye from aqueous solution. Journal of Environmental Management, Vol. 90, No. 8, (June 2009), pp. (2755-2761), ISSN 0301-4797.

[20] El-Hendawy, A.N.A. (2009). An insight into the $\mathrm{KOH}$ activation mechanism through the production of microporous activated carbon for the removal of $\mathrm{Pb}^{2+}$ cations. Applied Surface Science, Vol. 255, No. 6, (January 2009), pp. (3723-3730), ISSN: 0169-4332.

[21] Elizalde-González, M.P. Mattusch, J. Peláez-Cid, A.A. \& Wennrich, R. (2007). Characterization of adsorbent materials prepared from avocado kernel seeds: natural, activated and carbonized forms. Journal of Analytical and Applied Pyrolysis, Vol. 78, No. 1, (January 2007), pp. (185-193), ISSN 0165-2370.

[22] Elizalde-González, M.P. \& Hernández-Montoya, V. (2008). Fruit seeds as adsorbents and precursors of carbon for the removal of anthraquinone dyes. International Journal of Chemical Engineering, Vol. 1, No. 2-3, pp. (243-253), ISSN 0974-5793.

[23] Elizalde-González, M.P. \& Hernández-Montoya, V. (2009). Removal of acid orange 7 by guava seed carbon: A four parameter optimization study. Journal of Hazardous Materials, Vol. 168, No. 1, (August 2009), pp. (515-522), ISSN 0304-3894.

[24] Elizalde-González, M.P. \& Hernández-Montoya, V. (2009). Guava seed as an adsorbent and as a precursor of carbon for the adsorption of acid dyes. Bioresource Technology, Vol. 100, No. 7, (April 2009), pp. (2111-2117), ISSN 0960-8524.

[25] Gimba, C.E., Turoti, M., Egwaikhide, P.A. \& Akporhonor, E.E. (2009). Adsorption of indigo blue dye and some toxic metals by activated carbons from coconut shells. Electronic Jorunal of Environmental, Agricultural and Food Chemistry, Vol. 8, No. 11, pp. (1194-1201), ISSN 1579-4377.

[26] Giraldo, L. \& Moreno-Piraján, J.C. (2008). Pb²+ adsorption from aqueous solutions on activated carbons obtained from lignocellulosic residues. Brazilian Journal of Chemical Engineering, Vol. 25, No. 1, (January 2008), pp. (143-151), ISSN 0104-6632.

[27] Haro, M., Ruiz, B., Andrade, M., Mestre, A.S., Parra, J.B., Carvalho, A.P. \& Ania, C.O. (2011). Dual role of copper on the reactivity of activated carbons from coal and lignocellulosic precursors. Microporous and Mesoporous Materials, In press, ISSN 1387-1811.

[28] Hernández-Montoya, V., Mendoza-Castillo, D.I., Bonilla-Petriciolet, A., Montes-Morán, M.A. \& Pérez-Cruz, M.A. (2011). Role of the pericarp of Carya illinoinensis as biosorbent and as precursor of activated carbon for the removal of lead and acid blue 25 in aqueous solutions. Journal of Analytical and Applied Pyrolysis, Vol. 92, No. 1, (September 2011), pp. (143-151), ISSN 0165-2370.

[29] Hernández-Montoya, V., Ramírez-Montoya, L.A., Bonilla-Petriciolet, A. \& MontesMoran, M. (2012). Optimizing the removal of fluoride from wáter using new carbons obtained by modification of nut shell with a calcium solution from egg shell. Biochemical Engineering Journal, In press, ISSN 1369-703X.

[30] Krishnan, K.A., Sreejalekshmi, K.G. \& Varghese, S. (2010). Adsorptive retention of citric acid onto activated carbon prepared from Havea braziliansis sawdust: Kinetic and isotherm overview. Desalination, Vol. 257, No. 1-3, (July 2010), pp. (46-52), ISSN 00119164 . 
[31] Mohamed, A. R., Mohammadi, M. \& Darzi, G.N. (2010). Preparation of carbon molecular sieve from lignocellulosic biomass: A review. Renewable and Sustainable Energy Reviews, Vol. 14, No. 6, (August 2010), pp. (1591-1599), ISSN 1364-0321.

[32] Mourao, P.A.M., Laginhas, C., Custodio, F., Nabais, J.M.V., Carrot, P.J.M. \& Ribeiro Carrott, M.M.L. (2011). Influence of oxidation process on the adsorption capacity of activated carbon from lignocellulosic precursors. Fuel Processing Technology, Vol. 92, No. 2, (February 2011), pp. (241-246), ISSN 0378-3820.

[33] Mussatto, S.I., Fernandez, M., Rocha, G.J.M., Orfao, J.J.M., Teixeira J.A. \& Roberto, I.C. (2010). Production, characterization and application of activated carbon from brewer's spent grain lignin. Bioresource Technology, Vol. 101, No. 7, (April 2010), pp. (2450-2457), ISSN 0960-8524.

[34] Namasivayam, C. \& Sangeetha, D. (2006). Recycling of agricultural solid waste, coir pith: Removal of anions, heavy metals, organics and dyes from water by adsorption onto $\mathrm{ZnCl}_{2}$ activated coir pith carbon. Journal of Hazardous Materials, Vol. 135, No. 1-3 (July 2006), pp. (449-452), ISSN 0304-3894.

[35] Ould-Idriss, A., Stitou, M., Cuerda-Correa, E.M., Fernández-González, C., MacíasGarcía, A., Alexandre-Franco, M.F. \& Gómez-Serrano, V. (2011). Preparation of activated carbons from olive-tree Wood revisited. II. Physical activation with air. Fuel Processing Technology, Vol. 92, No. 2, (February 2011), pp. (266-270), ISSN 0378-3820.

[36] Ozcimen, D. \& Ersoy-Mericboyu, A. (2009). Removal of copper from aqueous solutions by adsorption onto chestnut shell and grapeseed activated carbons. Journal of Hazardous Materials, Vol. 168, No. 2-3, (September 2009), pp. (1118-1125), ISSN 0304-3894.

[37] Puziy, A.M.; Poddubnaya, O.I.; Martínez-Alonso, A.; Castro-Muñiz, A.; Suárez-García, F. \& Tascón, J.M.D. (2007). Oxygen and phosphorus enriched carbons from lignocellulosic material. Carbon, Vol. 45, No. 10, (September 2007), pp. (1941-1950), ISSN 0008-6223.

[38] Satyanarayan, K.G., Guimaraes, J.L. \& Wypych, F. (2007). Studies on lignocellulosic fibers of Brazil. Part I: source, production, morphology, properties and applications. Composites: Part A, Vol. 38, No. 7, (July 2007), pp. (1694-1709), ISSN 1359-835X.

[39] Silvestre-Albero, A., Goncalvez, M., Itoh, T., Kaneko, K., Endo, M., Thommes, M., Rodríguez-Reinoso, F. \& Silvestre-Albero, J. (2012). Well-defined mesoporosity on lignocellulosic-derived activated carbons. Carbon, Vol. 50, No. 1, (January 2012), pp. (6672), ISSN 0008-6223.

[40] Sreejalekshmi, K.G., Anoop-Krishnan, K. \& Anirudhan, T.S. (2009). Adsorption of Pb(II) and $\mathrm{Pb}(\mathrm{II})$-citric acid on sawdust activated carbon: kinetic and equilibrium isotherm studies. Journal of Hazardous Materials, Vol. 161, No. 2-3, (January 2009), pp. (1506-1513), ISSN 0304-3894.

[41] Tajar, A.F., Kaghazchi, T. \& Soleimani, M. (2009). Adsorption of cadmium from aqueous solutions on sulfurized activated carbon prepared from nut shells. Journal of Hazardous Materials, Vol. 165, No. 1-3, (June 2009), pp. (1159-1164), ISSN 0304-3894.

[42] Timur, S., Kantarli, I.C., Onenc, S. \& Yanik, J. (2010). Characterization and application of activated carbon produced from oak cups pulp. Journal of Analytical and Applied Pyrolysis, Vol. 89, No. 1, (September 2010), pp. (129-136), ISSN 0165-2370.

[43] Valente Nabis, J.M., Gomez, J.A., Suhas, Carrott, P.J.M., Laginhas, C. \& Roman, S. (2009). Phenol removal onto novel activated carbons made from lignocellulosic precursors: influence of surface properties. Journal of Hazardous Materials, Vol. 167, No. 1-3, (August 2009), pp. (904-910), ISSN 0304-3894. 
[44] Wang, Z., Nie, E., Li J., Zhao Y., Luo X. \& Zheng Z. (2011). Carbons prepared from Spartina alterniflora and its anaerobically digested residue by $\mathrm{H}_{3} \mathrm{PO}_{4}$ activation: Characterization and adsorption of cadmium from aqueous solutions. Journal of Hazardous Materials, Vol. 188, No. 1-3, (April 2011), pp. (29-36), ISSN 0304-3894.

[45] Wojanárovits, L., Földváry, Cs.M. \& Takács E. (2010). Radiation-induced grafting of cellulose for adsorption of hazardous water pollutans: A review. Radiation Physics and Chemistry, Vol. 79, No. 8, (August 2010), pp. (848-862), ISSN 0969-806X.

[46] Wu, F.C., Tseng, R.L. \& Juang, R.S. (2005). Preparation of highly microporous carbons from fir wood by $\mathrm{KOH}$ activation for adsorption of dyes and phenols from water. Separation and Purification Technology, Vol. 47, No. 1-2, (December 2005), pp. (10-19), ISSN 1383-5866. 


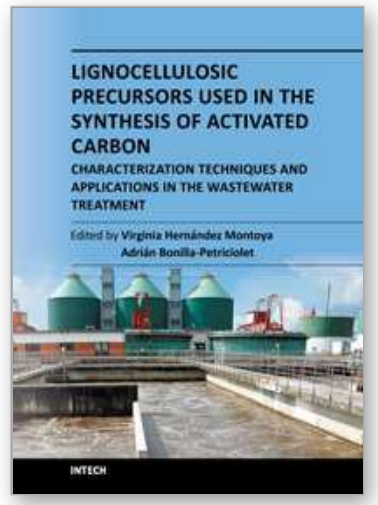

\author{
Lignocellulosic Precursors Used in the Synthesis of Activated \\ Carbon - Characterization Techniques and Applications in the \\ Wastewater Treatment \\ Edited by Dr. Virginia Hernández Montoya
}

ISBN 978-953-51-0197-0

Hard cover, 92 pages

Publisher InTech

Published online 29, February, 2012

Published in print edition February, 2012

The present book discusses the principal lignocellulosic precursors used in the elaboration of activated carbons in different countries such as Asia, America, Europe and Africa; the different methods and experimental conditions employed in the synthesis of activated carbons, including one analysis of the principal stages of the preparation such as carbonization and activation (i.e., chemical or physical activation). Also, the recent and more specialized techniques used in the characterization of activated carbons are discussed in this book. For example, the techniques employed to determine textural parameters (mercury porosimetry and gas adsorption isotherms at $77 \mathrm{~K}$ ) and different spectroscopies to determine chemical functionality (Raman, FT-IR, etc.) and other X-Ray techniques. Additionally, an overview of the application of activated carbons obtained from lignocellulosic precursors for wastewater treatment. Specifically, the analysis and discussion are focused on the advantages and capabilities of activated carbons for the removal of relevant toxic compounds and pollutants from water such as heavy metals, dyes, phenol, etc. Finally, the use of pyrolysis method for the valorization of two Mexican typical agricultural wastes (orange peel and pecan nut shell) for energy and carbon production is considered in this book.

\title{
How to reference
}

In order to correctly reference this scholarly work, feel free to copy and paste the following:

María del Rosario Moreno-Virgen, Rigoberto Tovar-Gómez, Didilia I. Mendoza-Castillo and Adrián BonillaPetriciolet (2012). Applications of Activated Carbons Obtained from Lignocellulosic Materials for the Wastewater Treatment, Lignocellulosic Precursors Used in the Synthesis of Activated Carbon Characterization Techniques and Applications in the Wastewater Treatment, Dr. Virginia Hernández Montoya (Ed.), ISBN: 978-953-51-0197-0, InTech, Available from: http://www.intechopen.com/books/lignocellulosicprecursors-used-in-the-synthesis-of-activated-carbon-characterization-techniques-and-applications-in-thewastewater-treatment/no-title-specified-3

\section{INTECH}

open science | open minds

\section{InTech Europe}

University Campus STeP Ri

Slavka Krautzeka 83/A

51000 Rijeka, Croatia

Phone: +385 (51) 770447

\section{InTech China}

Unit 405, Office Block, Hotel Equatorial Shanghai

No.65, Yan An Road (West), Shanghai, 200040, China

中国上海市延安西路65号上海国际贵都大饭店办公楼 405 单元

Phone: +86-21-62489820 
Fax: +385 (51) 686166

Fax: +86-21-62489821

www.intechopen.com 
(C) 2012 The Author(s). Licensee IntechOpen. This is an open access article distributed under the terms of the Creative Commons Attribution 3.0 License, which permits unrestricted use, distribution, and reproduction in any medium, provided the original work is properly cited. 